\title{
Initial impacts of Microcystis aeruginosa blooms on the aquatic food web in the San Francisco Estuary
}

\author{
P. W. Lehman • S. J. Teh • G. L. Boyer • \\ M. L. Nobriga $\cdot$ E. Bass $\cdot$ C. Hogle
}

Received: 11 May 2009/Revised: 10 November 2009/Accepted: 16 November 2009/Published online: 6 December 2009

(C) The Author(s) 2009. This article is published with open access at Springerlink.com

\begin{abstract}
The impact of the toxic cyanobacterium Microcystis aeruginosa on estuarine food web production in San Francisco Estuary is unknown. It is hypothesized that Microcystis contributed to a recent decline in pelagic organisms directly through its toxicity or indirectly through its impact on the food web after 1999. In order to evaluate this hypothesis, phytoplankton, cyanobacteria, zooplankton, and fish were collected biweekly at stations throughout the estuary in 2005. Concentrations of the tumor-promoting Microcystis toxin, microcystin, were measured in water, plankton, zooplankton, and fish by a protein phosphatase inhibition assay, and fish health was assessed by histopathology. Microcystis abundance
\end{abstract}

Handling editor: D. P. Hamilton

P. W. Lehman $(\bowtie) \cdot$ E. Bass · C. Hogle

Division of Environmental Services, California

Department of Water Resources, Sacramento,

CA 95691, USA

e-mail: plehman@water.ca.gov

\section{S. J. Teh}

Department of Veterinary Medicine, University of California, Davis, CA 95616, USA

\section{G. L. Boyer}

College of Environmental Science and Forestry, State

University of New York, Syracuse, NY 13210, USA

\section{L. Nobriga}

Water Branch, California Department of Fish and Game,

Sacramento, CA 95811, USA was elevated in the surface layer of the western and central delta and reached a maximum of $32 \times 10^{9}$ cells $1^{-1}$ at Old River in August. Its distribution across the estuary was correlated with a suite of phytoplankton and cyanobacteria species in the surface layer and $1 \mathrm{~m}$ depth including Aphanizomenon spp., Aulacoseira granulata, Bacillaria paradoxa, Rhodomonas spp., and Cryptomonas spp. Shifts in the phytoplankton community composition coincided with a decrease in the percentage of diatom and green algal carbon and increase in the percentage of cryptophyte carbon at $1 \mathrm{~m}$ depth. Maximum calanoid and cyclopoid copepod carbon coincided with elevated Microcystis abundance, but it was accompanied by a low cladocera to calanoid copepod ratio. Total microcystins were present at all levels of the food web and the greater total microcystins concentration in striped bass than their prey suggested toxins accumulated at higher trophic levels. Histopathology of fish liver tissue suggested the health of two common fish in the estuary, striped bass (Morone saxatilis), and Mississippi silversides (Menidia audens), was impacted by tumor-promoting substances, particularly at stations where total microcystins concentration was elevated. This study suggests that even at low abundance, Microcystis may impact estuarine fishery production through toxic and food web impacts at multiple trophic levels.

Keywords Microcystis · Phytoplankton species composition · Fish histopathology · 
Food web - Microcystins - Cyanobacteria · Protein phosphate inhibition assay

\section{Introduction}

Microcystis aeruginosa (Microcystis) is a cyanobacterium species that can form harmful algal blooms $(\mathrm{CHAB})$ in freshwater water bodies world wide (Chorus, 2005). Its distribution has spread into some estuaries including the Chesapeake Bay, the San Francisco Bay, and the Neuse River in the USA, the Swan River in Australia, and the Guadiana River in Spain and Portugal (Paerl, 1988; Sellner et al., 1988; Rocha et al., 2002; Robson \& Hamilton, 2003, 2004; Lehman et al., 2005). Microcystis is considered a toxic $\mathrm{CHAB}$ because some species contain powerful hepatotoxins called microcystins that initiate cancer and promote tumor formation in the liver of humans and wildlife (Zegura et al., 2003; International Agency for Research on Cancer, 2006; Ibelings \& Havens, 2008). It also produces a surface scum that impedes recreation, reduce aesthetics, lower dissolved oxygen concentration, and cause taste and odor problems in drinking water (Paerl et al., 2001). Microcystis and other freshwater cyanobacteria blooms are currently a worldwide concern because their frequency and distribution are increasing (Fristachi et al., 2008). Although the potential impact of Microcystis blooms on human health is known, its potential impact on the structure and function of aquatic food webs is poorly understood (Ibelings \& Havens, 2008).

Microcystis can affect phytoplankton community composition through allelopathy (Legrand et al., 2003). Cyanobacteria produce a large array of metabolites including organic and amino acids, peptides, alkaloids, carbohydrates, and lipopolysaccharides that can affect higher trophic levels (Paerl et al., 2001; Smith et al., 2008). Differential response of phytoplankton and cyanobacteria (plankton) to these allelopathic substances affects plankton community composition and species diversity in laboratory cultures (Sedmak \& Kosi, 1998; Suikkanen et al., 2005). In nature, the response of the plankton community is variable and probably depends on environmental conditions (Graneli et al., 2008), but the full impact of Microcystis on plankton communities in the field is poorly understood.
Many studies have demonstrated the effect of Microcystis or its toxins on zooplankton growth and survival. Microcystins either in zooplankton food or dissolved in the water column affect survival and growth rate of copepods, cladocera, and rotifers (Ghadouani et al., 2006; Federico et al., 2007). Secondary metabolites such as lipopolysaccharides in some non-toxic Microcystis strains can also inhibit zooplankton growth (Rohrlack et al., 2001, 2005). The greatest impact of Microcystis on natural zooplankton populations may be its poor food quality (Wilson et al., 2006). Low concentrations of polyunsaturated and saturated fatty acids compared with other plankton make Microcystis a nutritionally poor quality food (Müller-Navarra et al., 2000). The large diameter of the Microcystis colonies also makes them difficult to ingest, may physically clog feeding appendages and increase food rejection rate (Ghadouani et al., 2004). In addition, the presence of Microcystis in the water column and associated production of protease inhibitors may inhibit feeding in some zooplankton (Agrawai et al., 2001; FerrãoFilho et al., 2002). Some or all of these factors may explain field and laboratory research which suggests Microcystis alters zooplankton community structure and total biomass by reducing the growth and survival of zooplankton, especially large ( $>1 \mathrm{~mm}$ ) cladocerans like Daphnia (Ghadouani et al. 2006; Chen et al., 2007). The response of the zooplankton community to Microcystis is complex and depends on a variety of factors including season, length of exposure, and the Microcystis strain and how these interact with the fitness of each zooplankton species (Gustafsson \& Hansson, 2004; Wilson \& Hay, 2007).

At higher trophic levels, Microcystis blooms affect fish health through impacts on growth rate, histopathology, and behavior (Malbrouck \& Kestemont, 2006). Microcystin enters the fish gut passively during swimming or actively through food intake, and accumulates in fish tissue (De Magalthães et al., 2001). Microcystin slows protein synthesis by inhibiting protein phosphatase 1 and $2 \mathrm{~A}$ and promotes tumor formation and cancer in fish tissue (Fischer \& Dietrich, 2000; van der Oost et al., 2003). Microcystin can increase heart rate and produce osmoregulatory imbalance by stimulating drinking in adults which makes fish more susceptible to toxins in the environment, including microcystin (Best et al., 2001, 2003). Recent research suggests microcystins also cause 
oxidative stress in fish by reducing the production of antioxidants and increasing lipid peroxidation in liver, kidney, and gill tissue (Bláha et al. 2004; Prieto et al., 2007). The lipopolysaccharides in Microcystis cells further decrease antioxidant formation in fish and may be more toxic than microcystin (Best et al., 2002). At a population level, Microcystis causes effects such as mortality and delayed hatching in fish embryos or may simply affect feeding rate (Malbrouck \& Kestemont, 2006; Palíková et al., 2007).

Microcystis blooms are a fairly recent occurrence in San Francisco Estuary (SFE), and were first observed in the delta region in 1999 (Lehman et al., 2005). The population level during the summer bloom period is relatively low when compared with many Microcystis blooms worldwide which form a dense scum on the surface of the water column (Lehman et al., 2008). It is unknown, if this bloom is still in its initial stage of establishment, or has reached maximum abundance. Recent genetic studies indicate the Microcystis strain in SFE is genetically different from known strains (Moisander et al., 2009). However, the coincident appearance of Microcystis and a decline in a number of fish and zooplankton species of concern including delta smelt (Hypomesus transpacificus), striped bass (Morone saxatilis), and threadfin shad (Dorosoma petenense) and their calanoid copepod prey Eurytemora affinis and Pseudodiaptomus forbesii in the freshwater regions of the estuary suggest that there is a link between the fishery decline and the presence of Microcystis in the estuary since 2000 (Sommer et al., 2007). Research on Microcystis in 2003 and 2004 confirmed the presence of toxic microcystins in plankton and zooplankton in SFE (Lehman et al., 2005, 2008). We hypothesize that Microcystis directly or indirectly contributed to the decline in fish and zooplankton species of concern through toxicity or impacts on the food web.

The purpose of this study was to utilize a combination of plankton, zooplankton, and fish community composition, tissue microcystins concentration, and histopathology to determine if Microcystis may have influenced the production or health of organisms in the estuarine food web in 2005. Such information is invaluable for developing strategies to manage future estuarine food web resources impacted by this toxic cyanobacterium. It may also assist with developing a more comprehensive understanding of the factors that contributed to the decline in pelagic organisms and increase in Microcystis blooms in SFE since 2000 (Lehman et al., 2005; Sommer et al., 2007).

\section{Materials and methods}

Study area

San Francisco Estuary (SFE) consists of an inland delta that flows into a chain of downstream marine bays-Suisun, San Pablo, and San Francisco-and creates one of the largest estuaries on the west coast of North America (Fig. 1). The Sacramento River on the north and the San Joaquin River on the south converge just east of Suisun Bay to form a delta that contains $200 \mathrm{~km}^{2}$ of waterways. The Sacramento River is the largest of the rivers that feed the delta, and has an average discharge of $498 \pm 21 \mathrm{~m}^{3} \mathrm{~s}^{-1}$ compared with $70 \pm 7 \mathrm{~m}^{3} \mathrm{~s}^{-1}$ for the San Joaquin River over the August and September period of this study. The delta has many kinds of habitats from shallow flooded islands that are $2 \mathrm{~m}$ deep to wide and deep river channels that are $13 \mathrm{~m}$ deep. Flow in the delta is influenced by tides that reach $2 \mathrm{~m}$ in depth, tidal velocities up to $30 \mathrm{~cm} \mathrm{~s}^{-1}$ and tidal excursions of up to $10 \mathrm{~km}$. The delta is largely rural with a population of about 500,000 people within the cities of Sacramento, Stockton, and West Sacramento. Most of the $1,300 \mathrm{~km}$ of sloughs and 57 islands in the delta are used for agriculture and wildlife habitat.

Field sampling

Chlorophyll $a$ and total microcystins concentration plus a suite of water quality conditions were sampled biweekly at each station between August 1 and September 30, 2005 at 10 stations throughout the freshwater to brackish water reaches of SFE (Fig. 1). Stations were selected that reflected different habitats within the delta including the brackish water habitat in Suisun Bay at Chipps Island (CI) and Middle Ground (SB), saltwater marsh habitat at Montezuma Slough (SM), freshwater habitat in the Sacramento River at Cache Slough (CS), the San Joaquin River at Turner Cut (SJ) and Old River near Ranch del Rio (OR), brackish water habitat in the Sacramento River at Collinsville (CV) and the San Joaquin River at 
Fig. 1 Map of San Francisco estuary showing codes for sampling stations for Napa River (NR) at the City of Napa, Suisun Bay at Middle Ground (SB),

Suisun Marsh at Montezuma Slough (SM), Chipps Island (CI), Sacramento River at Collinsville (CV) and Cache Slough (CV), Old River at Franks Tract (FT) and Ranch del Rio (OR), and San Joaquin River at Turner Cut (SJ) and Antioch (AT)

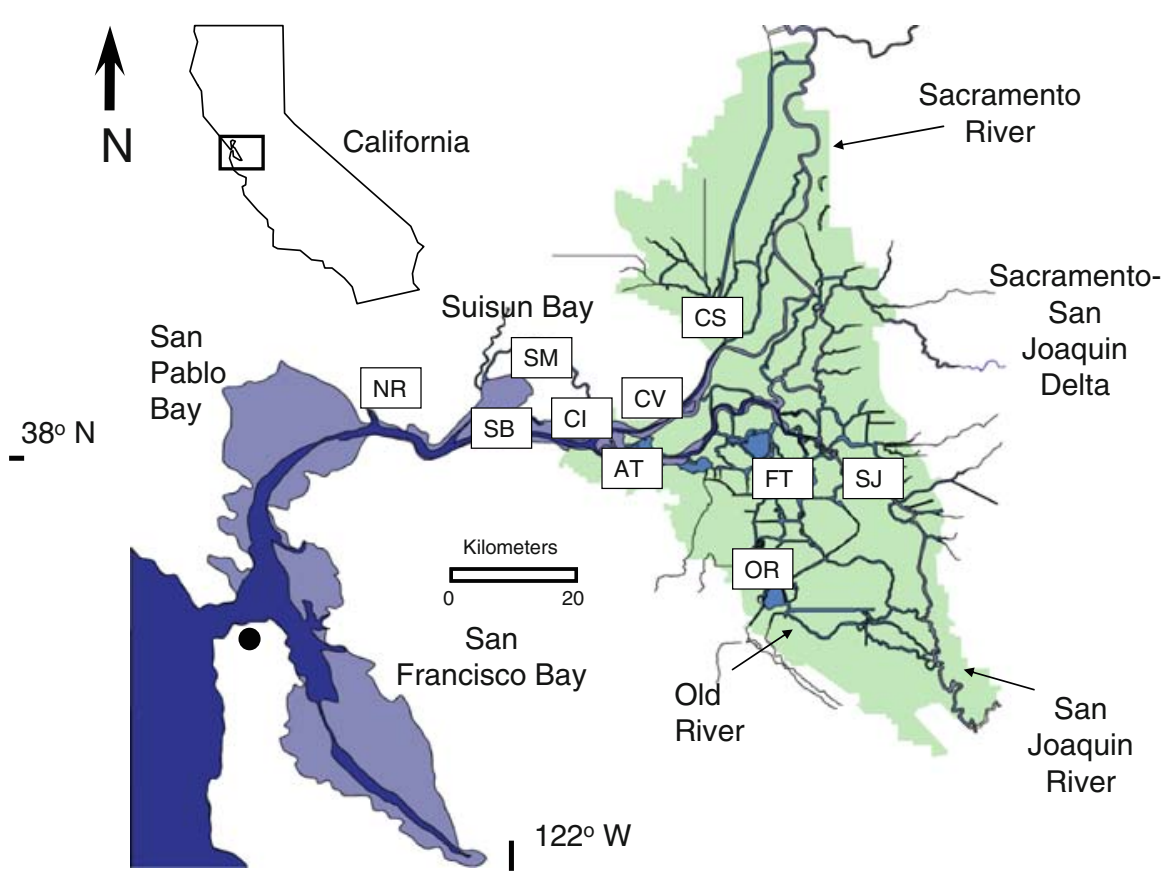

Antioch (AT), and flooded island habitat in Old River at Franks Tract (FT). A station was added in the Napa River (NR) outside of the delta which did not have a Microcystis bloom for perspective.

Microcystis colonies in the surface layer were sampled by horizontal surface tows of a $0.5 \mathrm{~m}$ diameter plankton net with $75 \mu \mathrm{m}$ mesh netting as described in Lehman et al. (2005). Water samples containing plankton biomass were stored at $4^{\circ} \mathrm{C}$ and filtered within $2 \mathrm{~h}$ onto Millipore APFF glass fiber filters. Filters for microcystins analysis were folded, wrapped in aluminum foil, frozen, and stored at $-80^{\circ} \mathrm{C}$ until laboratory analysis for toxin content. Filters for chlorophyll $a$ analysis were preserved with $1 \mathrm{ml}$ of saturated magnesium carbonate solution, immediately frozen and stored at $-14^{\circ} \mathrm{C}$ until analysis for pigment content.

Pigments were extracted from glass fiber filters in 90\% acetone and analyzed for chlorophyll $a$ (corrected for phaeophytin) and phaeophytin using spectrophotometry (American Public Health Association et al., 1998). Water samples for identification and enumeration of plankton were preserved and stained with Lugol's iodine solution, and phytoplankton were counted at $\times 700$ using an inverted microscope technique (Utermöhl, 1958). This magnification allowed clear identification of plankton cells $>6 \mu \mathrm{m}$ in diameter. Phytoplankton species were identified by taxonomic descriptions in Freshwater Algae of North America, Ecology, and Classification (Wehr \& Sheath, 2003) and Cyanoprokaryota 1, Teil: Chroococcales (Komárek \& Anagnostidis, 2001). Microcystis aeruginosa was identified as the only Microcystis species in each sample. Plankton cell carbon was calculated from cell volume computed from cell dimensions applied to simple geometrical shapes with correction for the small plasma volume in diatom cells (Menden-Deuer \& Lessard, 2000).

Water quality conditions were determined from laboratory analysis of water collected near the surface using a van Dorn bottle sampler. Water samples for chloride, alkalinity, ammonium-N, nitrate-N plus nitrite-N, soluble reactive phosphorus, and silicate concentration were filtered through $0.45 \mu \mathrm{m}$ pore size Millipore HATF04700 nucleopore filters. Water samples for dissolved organic carbon were filtered through Millipore APFF glass fiber filters. Filtered and raw water samples were either stored at $4^{\circ} \mathrm{C}$ or $-14^{\circ} \mathrm{C}$ until analysis for nutrients (United States Environmental Protection Agency, 1983; United States Geological Survey, 1985) or dissolved microcystins analysis. Total suspended solids, total and dissolved organic carbon concentration, and alkalinity were determined by standard methods (American Public Health Association et al., 1998). Water temperature, $\mathrm{pH}$, specific conductance, and dissolved oxygen were measured 
near the surface using a Yellow Springs Instrument (YSI) 6600 water quality sonde.

Zooplankton were collected at each station by a 3 min diagonal tow of a $0.5 \mathrm{~m}$ diameter plankton net fitted with a $150 \mu \mathrm{m}$ mesh netting. Zooplankton were kept at $4{ }^{\circ} \mathrm{C}$ and separated by pipette from Microcystis in the water sample using a dissecting microscope within $48 \mathrm{~h}$ of sampling. Zooplankton tissue was rinsed in distilled water and frozen at $-80^{\circ} \mathrm{C}$ until toxin analysis. Zooplankton for identification and enumeration were dyed and preserved in $10 \%$ buffered formalin with rose bengal dye. Species identification and enumeration were conducted using a dissecting scope.

Juvenile striped bass (Morone saxatilis) and Mississippi silversides (Menidia audens) were collected at beaches near the edge of channels adjacent to the open water sampling station. Juvenile striped bass and Mississippi silversides were selected for this study because they occur throughout the estuary and prey on mesozooplankton and amphipods that may use Microcystis as a food source. Fish were sampled using a $30 \times 1.8 \mathrm{~m}, 3.2 \mathrm{~mm}$ mesh beach seine. Sampling consisted of 2-8 hauls per station during flood tide when beaches were covered in water. Fish $30-300 \mathrm{~mm}$ were most vulnerable to this beach seine sampling technique (Nobriga et al., 2005). Live striped bass and Mississippi silversides were immediately placed in a cooler with river water, aerated with a stone aerator, and transported to a nearby laboratory boat for dissection. Only live fish were dissected for tissue analysis. Juvenile striped bass were not collected in sufficient quantity for analysis at FT and OR.

Fish were decapitated, and liver and muscle were surgically removed from each fish in less than $1 \mathrm{~h}$ after collection. The liver tissue of each fish was partitioned into two samples: one for analysis of total microcystins content and one for histopathology. For total microcystins analysis, tissue was wrapped in aluminum foil, flash frozen with liquid nitrogen and kept frozen at $-80^{\circ} \mathrm{C}$ until analysis. Tissue samples for histopathological analysis were stored at room temperature in $10 \%$ neutral buffered formalin. Because the fish were small (typically $<100 \mathrm{~mm}$ long), liver and muscle tissues from multiple striped bass were combined to get sufficient tissue for microcystins analysis. Mississippi silversides were so small that liver and muscle tissue could not be separated.
Microcystins analysis

Filters with plankton tissue for total microcystins analysis were extracted by sonication with $10 \mathrm{ml}$ of $50 \%$ methanol containing $1 \%$ acetic acid, clarified by centrifugation, and the extract used for toxic microcystins analysis using the protein phosphatase inhibition assay (PPIA) technique, while anatoxin-a in plankton samples was measured by HPLC as described in Lehman et al. (2005). Dissolved microcystin concentration was computed as the difference between whole water and plankton tissue concentrations.

The toxic microcystins concentration in fish tissue was determined from lyophilized tissue $(0.1 \mathrm{~g} \mathrm{dw}$ liver or $0.6 \mathrm{~g} \mathrm{dw}$ muscle) that was extracted with $50 \%$ methanol $(\mathrm{MeOH})$ containing $1 \%$ acetic acid (HOAc) at a ratio of $10 \mathrm{ml}$ solvent: $1 \mathrm{~g} \mathrm{dw}$ tissue. The tissue was homogenized using a Biospec tissue tearor at $5,000-10,000 \mathrm{rpm}$ for $1 \mathrm{~min}$ and then centrifuged at 3,000 rpm for $10 \mathrm{~min}$. The supernatant was transferred to a glass tube, and the particulate material was re-extracted with the same volume of solvent. The pooled supernatants were taken to dryness in vacuo and resuspended in $1 \mathrm{ml}$ of acidified $50 \% \mathrm{MeOH}$. PPIA was used to determine the total concentration of free microcystins, expressed as microcystin-LR equivalents, in the fish tissue. The PPIA method used for fish tissue was the same as that used for plankton and zooplankton tissue described above. The recovery of free microcystins in fish tissue was determined using an internal standard, [S-propyl-cys ${ }^{7}$ ] microcystin-LR, synthesized from microcystin-LR (Smith \& Boyer, 2009).

\section{Histopathology}

Histopathological analysis was conducted on fish liver tissue following the methods of Teh et al. (2004). After $48 \mathrm{~h}$ in $10 \%$ neutral buffered formalin, tissues were dehydrated in a graded ethanol series and embedded in a paraffin block. For each tissue block, serial sections ( $4 \mu \mathrm{m}$ thick) were cut and stained with hematoxylin and eosin. Tissue sections were examined under a BH-2 Olympus microscope for common and/or significant lesions.

Tissues were screened and scored on an ordinal ranking system for a variety of histopathological features and lesions $(0=$ none $/$ minimal, $1=$ mild, $2=$ moderate, and $3=$ severe and $0=$ not present or 
infrequently observed, $1=$ mildly affected in $<10 \%$ of the tissue, $2=$ moderately affected in $10-50 \%$ of the tissue, and $3=$ severely affected in greater than $50 \%$ of the tissue, respectively). Due to the importance of the number of preneoplastic foci and tumors in the progression of fish hepatocarcinogenesis, basophil preneoplastic focus and hepatocellular adenoma lesions were enumerated rather than scored by severity.

Seven characteristics of the liver lesions were scored to identify toxic exposure in fish: glycogen depletion, eosinophilic protein droplets, cytoplasmic inclusions, single cell necrosis, fatty vacuolation, or lipidosis, macrophage aggregates and focal/multifocal parenchymal leukocytes or lymphocytes. Glycogen depletion was characterized by decreased hepatocyte size, loss of the 'lacy', irregular, and poorly demarcated cytoplasmic vacuolation typical of glycogen, and increased cytoplasmic basophilia (i.e., blue coloration). Eosinophilic protein droplets were characterized by the presence of proteins which appeared as refractile, eosinophilic (pink coloration), round, and well-demarcated cytoplasmic vacuoles. Cytoplasmic inclusions were characterized by the accumulation of foreign materials within the cytoplasm of hepatocytes. Single cell necrosis was characterized by cells having eosinophilic cytoplasm with nuclear pyknosis and karyorrhexis. Fatty vacuolation or lipidosis was characterized by excess lipids which appeared as clear, round, and well-demarcated cytoplasmic vacuoles. Macrophage aggregation was characterized as a cluster of macrophages packed with coarsely granular yellow-brown pigment. Focal/ multifocal parenchymal leukocytes or lymphocytes were characterized by focal to multifocal aggregates of lymphocytes, occasionally mixed with other inflammatory cells. Cumulative assessment was based on the sum of the mean of individual lesion scores where higher total mean score indicated poorer fish conditions.

\section{Statistical analysis}

Due to the lack of normality in the data sets, all statistical analyses were computed using non-parametric statistics. Comparisons of physical, chemical, and biological data were computed using non-parametric statistical techniques for single and multiple comparisons, Wilcoxon and Kruskal-Wallis comparison tests (SAS, 2004). Correlation coefficients were computed using the non-parametric Spearman rank correlation coefficient $\left(r_{\mathrm{s}}\right)$. Data were reported as the mean \pm the standard deviation.

Similar patterns in plankton and zooplankton community composition or carbon and their correlation with environmental factors were evaluated with Primer-e version 6 software (Clarke, 1993; Clarke \& Gorley, 2006) using a combination of multidimensional scaling (MDS), analysis of similarities among data (ANOSIM), identification of variables that best explain the data variance (BEST), and multivariate comparisons of data patterns (RELATE). These were applied to patterns in plankton species composition over space or time by visualizing the data patterns using an MDS of the Bray Curtis dissimilarity index computed from the square root of density or carbon data. Similar patterns in plankton or zooplankton community composition and carbon among stations were quantified with ANOSIM, while similarities between patterns in physical (normalized) and plankton and zooplankton community composition or carbon were quantified by Spearman rank correlation coefficients using RELATE. Species which accounted for most of the variation in the plankton, zooplankton, or environmental data were identified by Spearman rank correlation coefficients applied to groups of variables using BEST.

\section{Results}

\section{Plankton}

Microcystis abundance was greatest $(P<0.01$, ANOSIM) in the western and central delta (stations CV, AT, FT, SJ, and OR). Average Microcystis abundance $\left(9 \times 10^{6}\right.$ cells $\left.1^{-1}\right)$ at these stations was nearly an order of magnitude greater than at Suisun Bay stations SB and CI $\left(1.0 \times 10^{6}\right.$ cells $\left.1^{-1}\right)$ or the outlying stations SM, CS, and NR where Microcystis did not occur (Fig. 2). In the western and central delta, Microcystis abundance was elevated at stations CV, $\mathrm{AT}$, and OR and significantly greater at stations OR and AT $(P<0.05)$. Spatial variability characterized Microcystis in the western and central delta where abundance ranged by orders of magnitude from no cells $1^{-1}$ at station $\mathrm{CV}$ in early August to $32 \times 10^{9}$ cells $1^{-1}$ at station OR in mid-August. 
Fig. 2 Microcystis abundance, carbon, and chlorophyll $a$ concentration at stations throughout the estuary

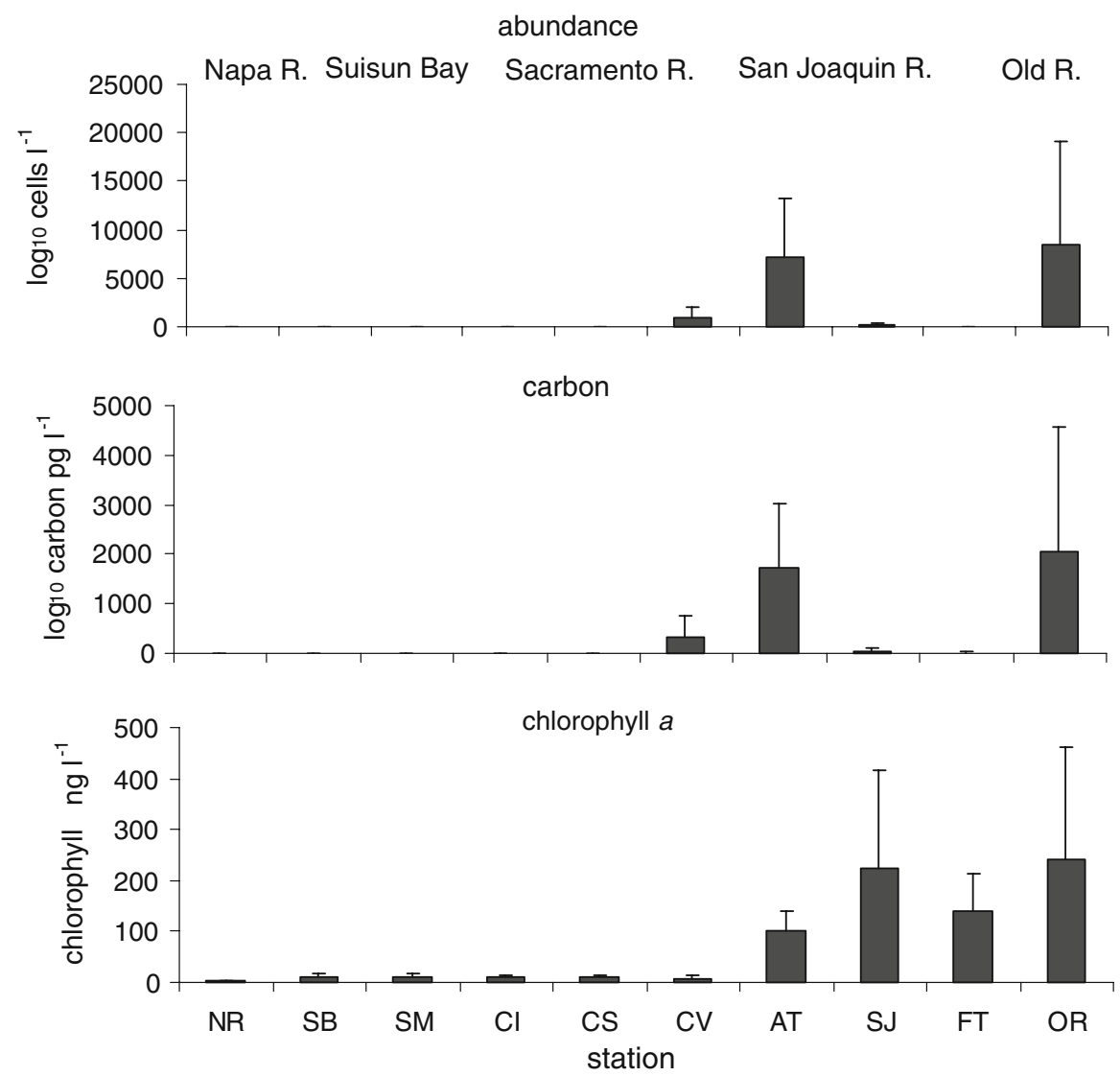

Chlorophyll a concentration increased with Microcystis carbon in the surface layer (Fig. 2). Microcystis carbon comprised about $90 \%$ of the plankton carbon, and was correlated with both total plankton carbon $\left(r_{\mathrm{s}}=0.83 ; P<0.01\right)$ and chlorophyll $a$ concentration $(r=0.76, P<0.01)$ for all stations combined. Microcystis carbon was also positively correlated with diatom, green algae, and miscellaneous flagellate carbon $\left(r_{\mathrm{s}}=0.43, P<0.01\right.$; $r_{\mathrm{s}}=0.74, \quad P<0.01, \quad$ and $r_{\mathrm{s}}=0.76, \quad P<0.01$, respectively). Chlorophyll $a$ concentration and total plankton carbon were also correlated $\left(r_{\mathrm{s}}=0.82\right.$; $P<0.01)$.

Plankton community composition varied with $M i$ crocystis abundance throughout the water column. In the surface layer, plankton community composition was correlated with Microcystis abundance for all stations combined $(P<0.01$, RELATE). The variation in this plankton community was primarily due to the cyanobacterium Aphanizomenon spp., diatoms Aulacoseira granualata and Bacillaria paradoxa, green alga Chlorella sp., and miscellaneous flagellates $\left(r_{\mathrm{s}}=0.94\right.$, BEST; Fig. 3). Microcystis comprised 5, $48,100,86,100$, and $95 \%$ of the total abundance at $\mathrm{SB}, \mathrm{CV}, \mathrm{AT}, \mathrm{SJ}, \mathrm{FT}$, and OR, respectively, and less than $1 \%$ at the rest of the stations. Microcystis abundance was also significantly correlated $(P<$ 0.05 , RELATE) with the plankton community composition in the western and central delta where Aphanizomenon sp., A. granulata and B.paradoxa accounted for $92 \%\left(r_{\mathrm{s}}=0.96\right.$, BEST $)$ of the variation. In addition, the abundance of cyanobacteria species including Aphanizomenon spp., Planktolyngbya spp., Pseudodanabaena spp., and Merismopedia spp. covaried ( $P<0.01$, RELATE) with Microcystis abundance for all stations combined (Fig. 3). The plankton community at $1 \mathrm{~m}$ depth was also correlated with Microcystis abundance in the surface layer for all stations $(P<0.05$, RELATE; Fig. 4$)$. About $83 \%$ of the variation in the plankton community at $1 \mathrm{~m}$ was associated with the abundance of the cryptophytes Rhodomonas spp. and Cryptomonas spp., the green 
Fig. 3 Average percent abundance of phytoplankton and cyanobacteria genera or species among stations. Only genera or species that comprised more than $1 \%$ of the abundance for any one station were included
Fig. 4 Percent carbon of phytoplankton and cyanobacteria genera or species at $1 \mathrm{~m}$ depth. Only genera or species that composed more than $1 \%$ of the abundance for any one station were included $\square$ Achnanthes spp.

$\boxminus$ Aulacoseira granulata

$\square$ centric diatom

Q Chlorella spp.

$\mathbb{\$}$ misc flagellate spp.

$\square$ Hydrosera whampoensis

$\square$ Merismopedia spp.

$\square$ Mougeotia spp.

$\square$ pennate diatom

$\square$ Rhodomonas spp.

$\square$ Synechocystis spp.

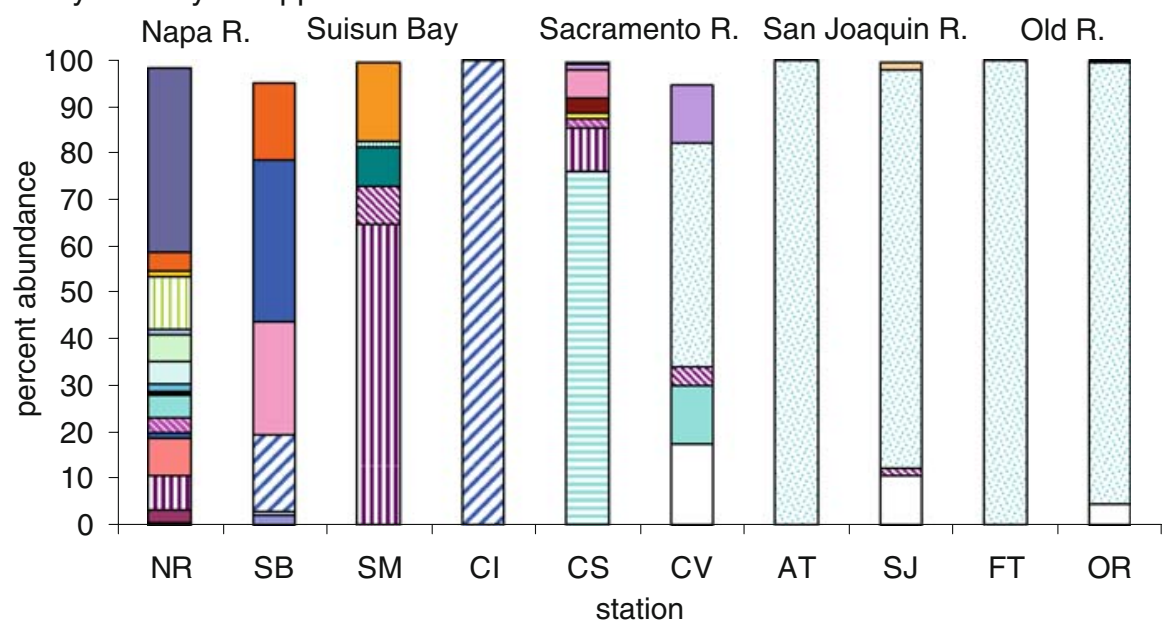

$\square$ Aphanizomenon spp.

$\square$ Anabaena spp.

II Bacillaria paradoxa

$\square$ Chaetoceros elmorei

$\square$ Coconeis spp.

Fragillaria spp.

$\square$ Kathablepharis ovalis

Microcystis aeruginosa

$\square$ Navicula spp.

$\square$ Planktolyngbya spp.

$\square$ Skeletonema potamos

$\square$ Carteria spp.

Clamydomonas spp.

$\square$ Cryptomonas spp.

$\checkmark$ Gyrosigma macrum

$\square$ Melosira spp.

$\square$ Monoraphidium spp.

$\square$ Pediastrum spp.

$\square$ Pseudoanabaena spp.

$\square$ Synedra spp. $\square$ Achnanthes spp.

$\square$ Carteria spp.

Chlamydomonas spp.

Chodatella spp.

目 Closterium setaceum

$\checkmark$ Cryptomonas spp.

$\mathbb{Q}$ Gymnodinium spp.

Microcystis aeruginosa

$\square$ Nitzschia spp.

Pseudanabaena spp.

$\square$ Scenedesmus quadricauda

$\square$ Stephanodiscus spp.

$\square$ Synechocystis spp.

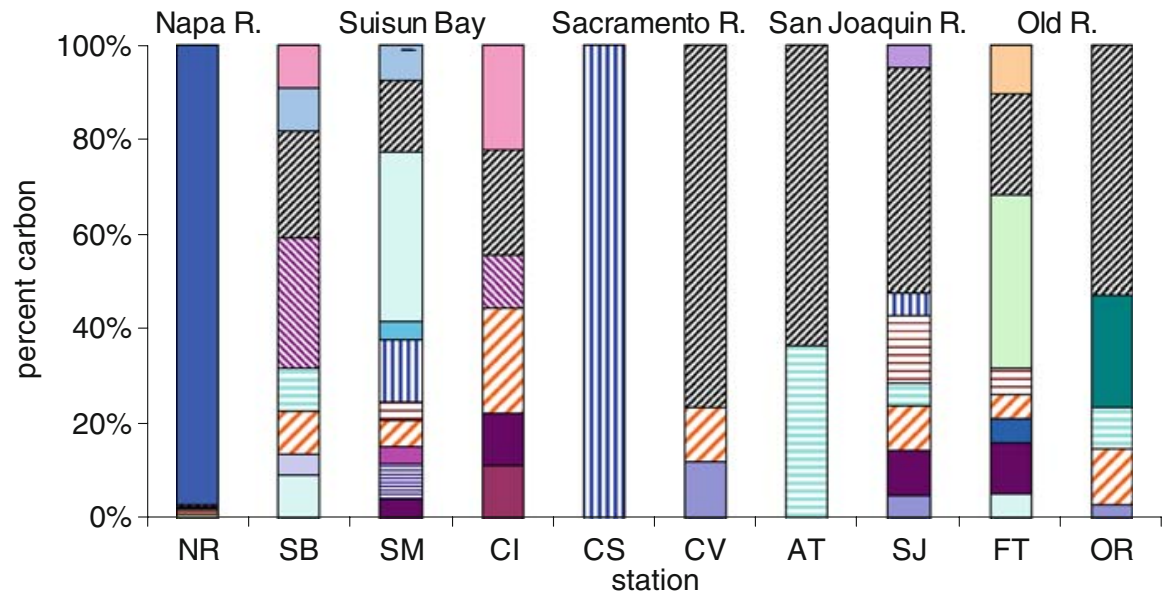


algae Closterium setaceum and Monoraphidium spp., and the dinoflagellate Gymnodinium spp. $\left(r_{\mathrm{s}}=0.91\right.$, BEST) which were abundant in the western and central delta; $50 \%$ of this variation was due to Rhodomonas spp. alone $\left(r_{\mathrm{s}}=0.71\right.$, BEST). Plankton community composition at $1 \mathrm{~m}$ depth was correlated with Microcystis abundance even on a small geographical scale. The cryptophytes Rhodomonas spp. and Cryptomonas spp., the cyanobacteria Merismopedia spp., and Microcystis and miscellaneous flagellates $\left(r_{\mathrm{s}}=0.86, \mathrm{BEST}\right)$ characterized differences in the plankton community at AT, OR, and CV compared with SJ and FT $(P<0.05$, ANOSIM $)$; most of this variation was due to Rhodomonas spp. $\left(r_{\mathrm{s}}=0.65\right.$, BEST). Microcystis abundance was similarly greater at AT and OR compared with SJ and FT $(P<0.05$, ANOSIM).

Differences in the plankton community composition affected the plankton carbon among groups. Plankton group carbon differed $(P<0.05$, ANOSIM) between stations $\mathrm{OR}, \mathrm{CV}$, and AT and stations FT and SJ at $1 \mathrm{~m}$ (Fig. 5). Most of this difference was associated with diatom, green algae, and cryptophyte carbon $\left(r_{\mathrm{s}}=0.89, \mathrm{BEST}\right)$, and was characterized by a greater $(P<0.05)$ percentage of cryptophytes and a lower $(P<0.05)$ percentage of diatoms and green algae at stations OR, CV, and AT compared with stations SJ and FT. The difference was most striking for cryptophyte carbon which comprised 70-90\% of the total carbon at OR, CV, and AT, but only 35-45\% of the total carbon for nearby stations at SJ and FT. Most of the cryptophyte carbon was produced by Rhodomonas sp. and Cryptomonas sp.

Microcystis abundance was correlated with water quality conditions across regions $(P<0.01$, RELATE). Water quality conditions differed $(P<0.01$, ANOSIM) among the western and central delta $(\mathrm{CV}, \mathrm{AT}, \mathrm{SJ}, \mathrm{FT}$, and OR), Suisun Bay (SB, SM, and CI), CS and NR stations or station groups (Table 1). About $72 \%$ (BEST) of this variation was correlated with chloride, total organic carbon, and total suspended solids concentration which increased seaward. Among variables, Microcystis abundance was negatively correlated with chloride $(P<0.01$, RELATE), total suspended solids $(P<0.01$, RELATE), and total organic carbon $(P<0.01$, RELATE), and positively correlated with nitrate-N $(P<0.05$, RELATE), soluble phosphorus $(P<0.05$, RELATE), and total nitrogen (nitrate-N plus ammonium-N; $P<0.01$, RELATE) concentration.

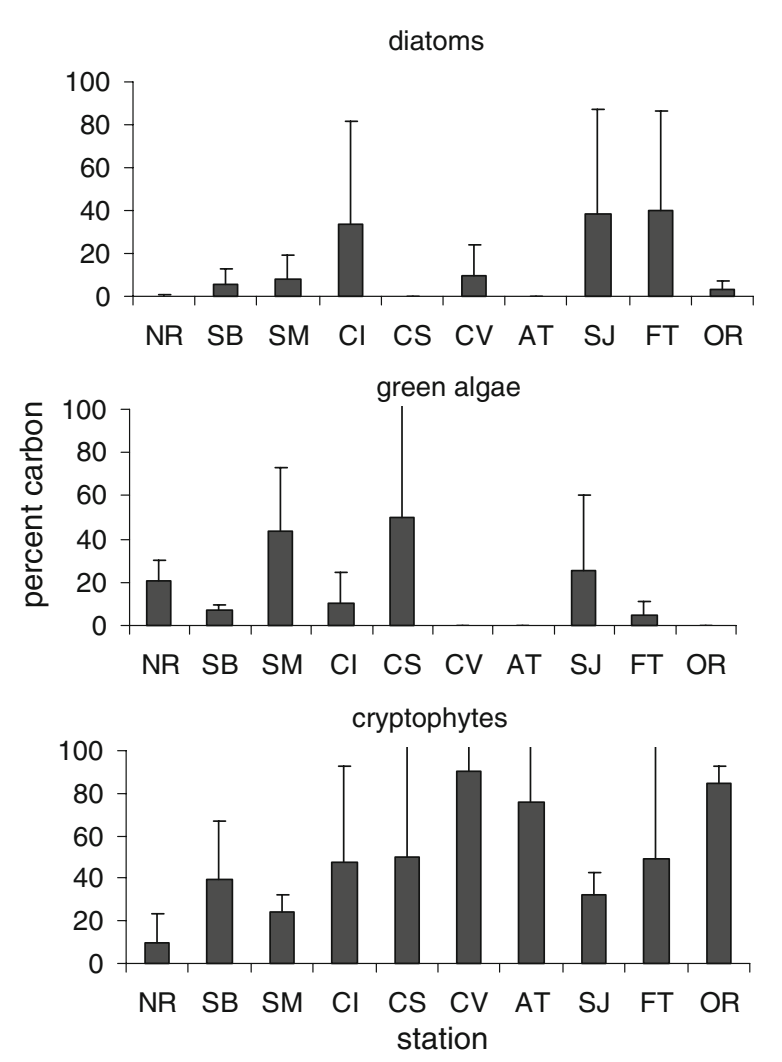

Fig. 5 Percent carbon for diatom, green algae, and cryptophyte carbon at $1 \mathrm{~m}$ depth

Although ammonium-N concentration was elevated at some stations in the western and central delta and the Sacramento River at stations at CS and CV, neither it nor the total nitrogen (nitrate- $\mathrm{N}$ and nitrite- $\mathrm{N}$ plus ammonium-N) to soluble phosphorus molar ratio (NP) was significantly correlated with Microcystis abundance across all regions or within the western and central delta separately. Plankton group carbon or plankton species abundance at $1 \mathrm{~m}$ was not significantly correlated with any of the water quality conditions measured, including the NP ratio.

\section{Zooplankton}

Zooplankton community composition differed $(P<0.01$, ANOSIM) across the delta and was correlated with Microcystis abundance in the surface layer $(P<0.01$, RELATE). Significant differences in the zooplankton community composition in the western and central delta and Suisun Bay $(P<0.01$, ANOSIM) 
Table 1 Average water quality conditions in the surface layer computed from biweekly data for stations sampled in the San Francisco Estuary between August and September 2005

\begin{tabular}{|c|c|c|c|c|c|c|c|c|c|c|}
\hline \multirow[t]{2}{*}{ Water quality variable } & \multicolumn{10}{|l|}{ Stations } \\
\hline & NR & SB & $\mathrm{SM}$ & $\mathrm{Cl}$ & CS & $\mathrm{CV}$ & AT & SJ & FT & OR \\
\hline Ammonium-N $\left(\mathrm{mg} \mathrm{l}^{-1}\right)$ & 0.01 & 0.03 & 0.02 & 0.03 & 0.10 & 0.05 & 0.03 & 0.03 & 0.02 & 0.02 \\
\hline Chloride $\left(\mathrm{mg} \mathrm{l}^{-1}\right)$ & $7,032.50$ & $2,655.00$ & $1,935.00$ & $2,420.00$ & 8.33 & 429.50 & 413.00 & 30.75 & 73.75 & 46.50 \\
\hline Nitrate-N $\left(\mathrm{mg} \mathrm{l}^{-1}\right)$ & 0.01 & 0.31 & 0.22 & 0.32 & 0.20 & 0.28 & 0.24 & 0.22 & 0.11 & 0.17 \\
\hline Dissolved organic carbon $\left(\mathrm{mg} \mathrm{l}^{-1}\right)$ & 2.93 & 1.65 & 4.30 & 1.71 & 1.90 & 1.72 & 1.82 & 2.09 & 2.00 & 1.89 \\
\hline Soluble reactive phosphorus $\left(\mathrm{mg} \mathrm{l}^{-1}\right)$ & 0.03 & 0.07 & 0.06 & 0.07 & 0.05 & 0.06 & 0.06 & 0.04 & 0.05 & 0.05 \\
\hline Silica $\left(\mathrm{mg}^{-1}\right)$ & 45.53 & 14.43 & 14.30 & 14.57 & 16.33 & 15.60 & 14.10 & 13.35 & 13.00 & 13.00 \\
\hline Alkalinity $\left(\mathrm{mg} \mathrm{l}^{-1}\right)$ & 121.00 & 69.00 & 80.25 & 69.67 & 69.67 & 67.25 & 66.00 & 61.25 & 65.25 & 62.50 \\
\hline Total organic carbon $\left(\mathrm{mg} \mathrm{l}^{-1}\right)$ & 3.20 & 1.71 & 4.65 & 1.99 & 1.85 & 1.90 & 1.86 & 2.05 & 1.85 & 2.13 \\
\hline Total phosphorus $\left(\mathrm{mg} \mathrm{l}^{-1}\right)$ & 0.08 & 0.10 & 0.14 & 0.15 & 0.10 & 0.09 & 0.09 & 0.08 & 0.08 & 0.08 \\
\hline Total suspended solids $\left(\mathrm{mg} \mathrm{l}^{-1}\right)$ & 10.38 & 23.75 & 41.25 & 61.00 & 20.33 & 34.25 & 9.75 & 3.75 & 2.50 & 2.75 \\
\hline Water temperature ${ }^{\circ} \mathrm{C}$ & 21.19 & 20.98 & 21.51 & 19.34 & 21.18 & 20.73 & 20.78 & 23.37 & 22.44 & 23.03 \\
\hline Dissolved oxygen $\left(\mathrm{mg} \mathrm{l}^{-1}\right)$ & 7.23 & 6.70 & 6.78 & 6.77 & 6.73 & 6.70 & 6.70 & 6.63 & 7.00 & 6.70 \\
\hline $\mathrm{pH}$ & 7.69 & 8.09 & 8.04 & 8.16 & 7.89 & 7.97 & 8.34 & 7.83 & 8.60 & 8.08 \\
\hline Specific conductance $\mu \mathrm{S} \mathrm{cm}-1$ & 18.80 & 7.69 & 5.73 & 7.22 & 0.16 & 1.38 & 1.73 & 0.23 & 0.36 & 0.21 \\
\hline
\end{tabular}
among stations determined from diagonal net tow samples

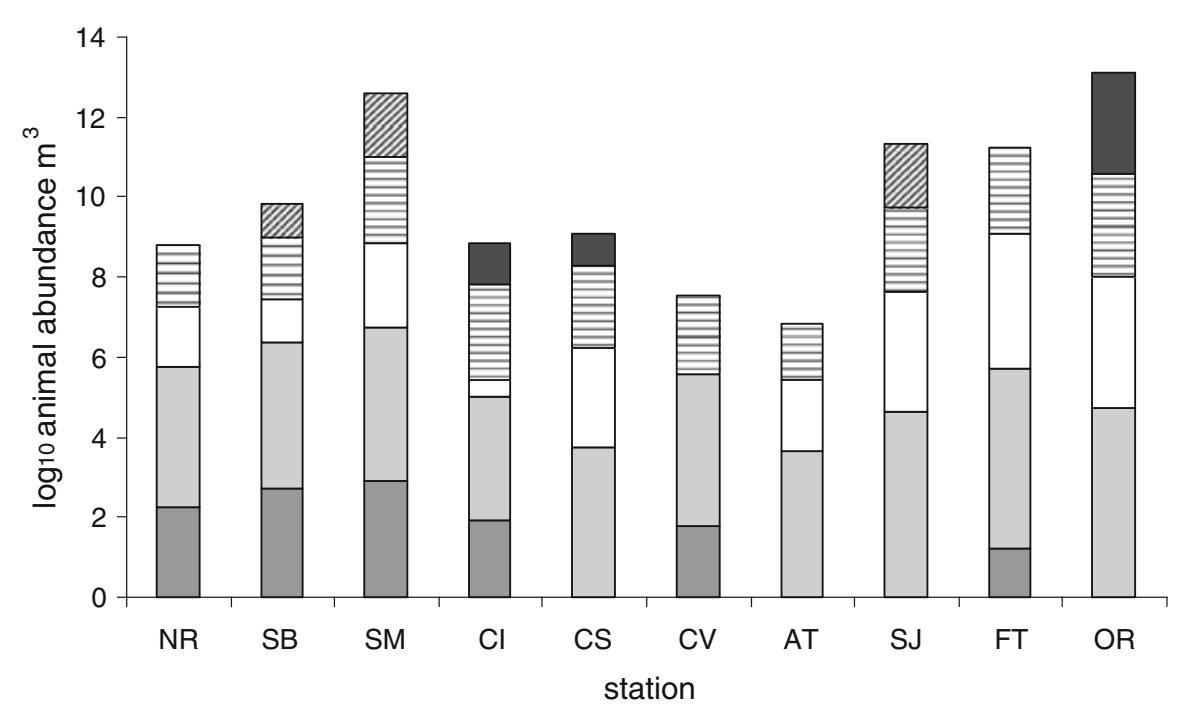

were also correlated with Microcystis abundance $(P<0.01$, RELATE). Most of the variation in the zooplankton community in the western and central delta and Suisun Bay was due to calanoid and cyclopoid copepods and cladocera $\left(r_{\mathrm{s}}=0.80, \mathrm{BEST}\right.$; Fig. 6). Calanoid copepods in the western and central delta were characterized by nauplii and the freshwater copepod Pseudodiaptomus spp., and were significantly different $(P<0.05$, ANOSIM) from Suisun Bay, where the brackish water calanoid copepod Acartiella spp. was abundant. Both Pseudodiaptomus spp. and Acartiella spp. accounted for $88 \%$ of the variation in the zooplankton community between the western and central delta and Suisun Bay $\left(r_{\mathrm{s}}=0.94, \mathrm{BEST}\right)$.

Microcystis carbon in the surface layer was significantly correlated with both total zooplankton carbon 
Fig. $7 \log _{10}$ average total and mesozooplankton group carbon $\left(\mu \mathrm{g} \mathrm{m}^{-3}\right)$ and their standard deviation (line) among stations determined from diagonal net tow samples

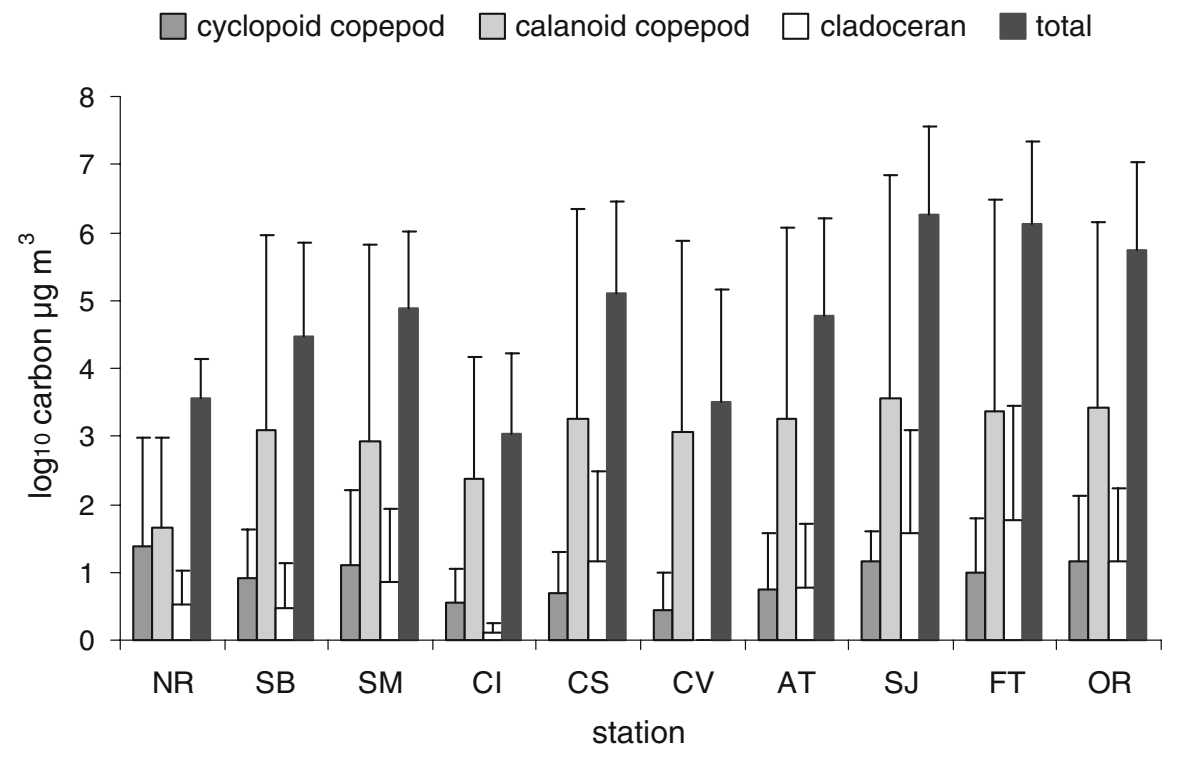

and zooplankton group carbon for all stations $(P<$ 0.01, RELATE) and for Suisun Bay and the western and central delta, separately $(P<0.01$, RELATE). Calanoid copepod, cyclopoid copepod, rotifer, and cladocera carbon differed $(P<0.01$, ANOSIM $)$ between Suisun Bay, the western and central delta and the outlying stations NR and CS (Fig. 7). Nearly all of this difference in carbon among stations was due to the high biomass of the calanoid copepod Pseudodiaptomus sp. in the central delta $\left(r_{\mathrm{s}}=0.99\right.$, BEST $)$. Although the zooplankton group carbon differed between stations CV, SJ, and OR in the western and central delta, it was not associated with Microcystis abundance (Fig. 7). In contrast, Microcystis carbon was associated with differences in the cladocera to calanoid copepod carbon ratio among stations in the western and central delta $(P<0.01$, RELATE). The cladocera to calanoid copepod carbon ratio was lower $(P<0.01)$ at stations OR, AT, and CV than FT and SJ $(0.003 \pm 0.003$ and $0.02 \pm 0.02$, respectively).

Toxins in plankton and animal tissue

Microcystins were present in the surface plankton samples throughout the estuary where Microcystis occurred (Fig. 8). The highest total microcystins concentration in Microcystis tissue $(P<0.05$, ANOSIM) occurred in the San Joaquin and Old rivers at stations AT, SJ, FT, and OR where it reached an average of $60 \mathrm{ng}^{-1}$. Total microcystins concentration was correlated with both chlorophyll $a$ concentration and Microcystis abundance for all stations $\left(r_{\mathrm{s}}=0.89\right.$, $\left.P<0.01 ; r_{\mathrm{s}}=0.74, P<0.01\right)$, the Suisun Bay and western and central delta $\left(r_{\mathrm{s}}=0.87, \quad P<0.01\right.$; $\left.r_{\mathrm{s}}=0.68, P<0.01\right)$, and the western and central delta $\left(r_{\mathrm{s}}=0.79, P<0.05 ; r_{\mathrm{s}}=0.45, P<0.05\right)$. The relative toxicity of Microcystis appeared to be uniform throughout the estuary because both total microcystins per unit chlorophyll $a$ concentration and total microcystins per Microcystis cell were not statistically different among stations, despite large differences in average values (Fig. 8). Dissolved total microcystins concentration was above detection limits nine times during the sampling season, three times in August at CI, CS, and OR (0.05-3.1 ng $\left.\mathrm{l}^{-1}\right)$, and six times in September at SB, CV, AT, FT, and OR (0.4$10.88 \mathrm{ng}^{-1}$ ). Anatoxin-a concentration was low and below detection limits in plankton samples 17 times during the summer; range 2.4-143 $\mathrm{pg}^{-1}$.

Total microcystins were present in zooplankton and amphipod tissue throughout the estuary. Total microcystins in zooplankton and amphipod tissue ranged from 0.40 to $1.43 \mu \mathrm{g}$ (g dry wt $)^{-1}$, and was greatest at $\mathrm{SJ}$ by a factor of 2 (Table 2). Low biomass precluded absolute measurements of total microcystins in most zooplankton and amphipod tissue samples. However, detection limits suggested average total microcystins concentration in animal tissue was low, and could only have reached as high as $3.99 \mu \mathrm{g}(\mathrm{g} \text { dry } \mathrm{wt})^{-1}$ in zooplankton and $0.99 \mu \mathrm{g}$ 
Fig. 8 Average (bar) and standard deviation (line) of total microcystins concentration $\left(\mu \mathrm{g}^{-1}\right)$, total microcystins per unit chlorophyll $a$ and total microcystins per Microcystis cell (within the $>75 \mu \mathrm{m}$ size fraction collected in surface net tows). Total microcystins were measured by protein phosphatase inhibition assay
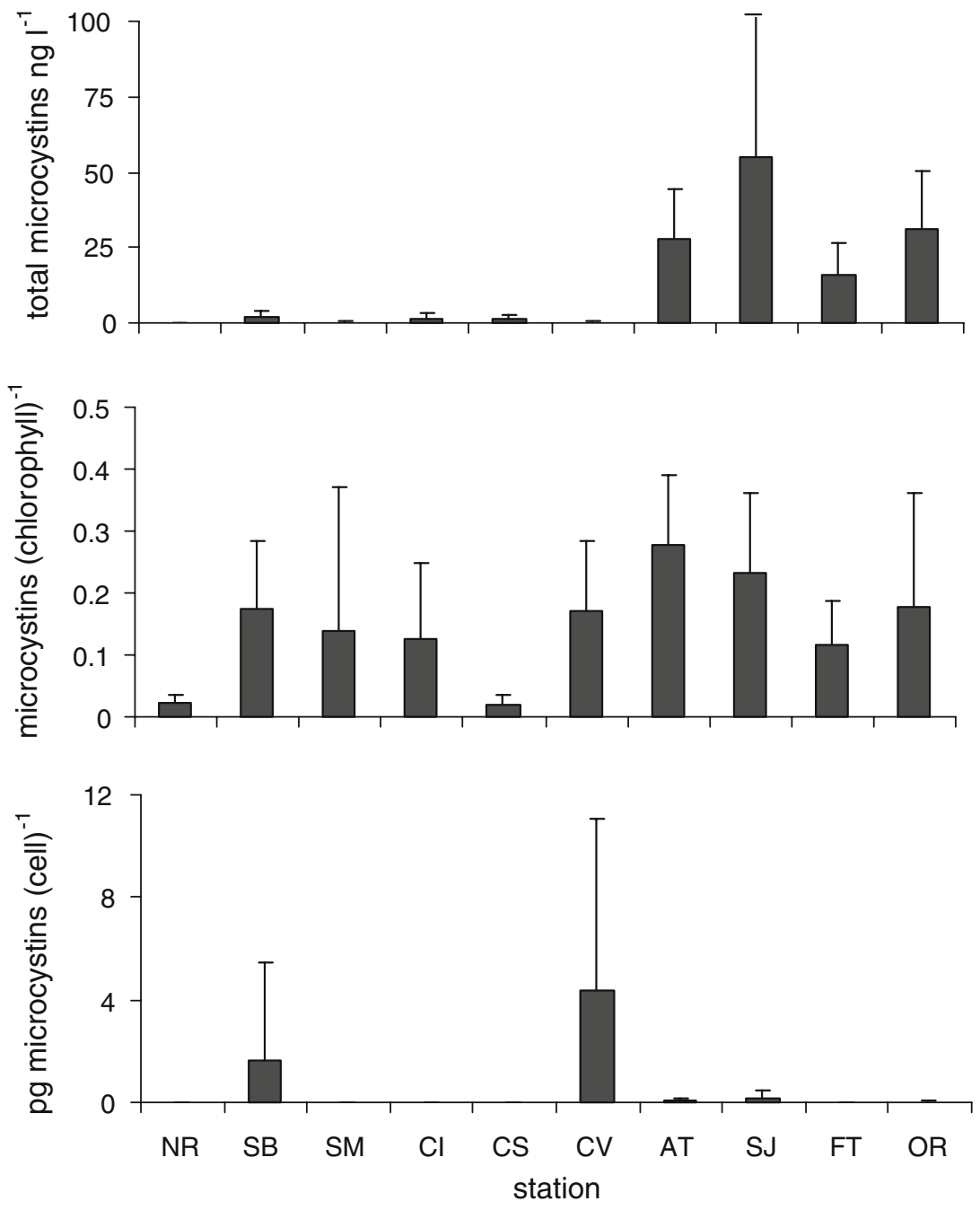

( $\mathrm{g}$ dry $\mathrm{wt})^{-1}$ in amphipod tissue in the central and western delta. A more thorough statistical evaluation of these trends was limited by the small sample size and qualitative nature of some of the data.

Total microcystins were present in the liver, muscle, and whole body tissues of juvenile striped bass and Mississippi silversides at all stations where fish occurred (Table 2). Total microcystins concentration in individual striped bass muscle tissue ranged by a factor of 3 from 1.03 to $3.42 \mu \mathrm{g}$ (g dry wt) ${ }^{-1}$, but averages among stations were similar (Table 2). Total microcystins concentration in striped bass liver tissue was slightly less than in muscle tissue and varied by a factor of 5 among samples (range 0.34-1.89 $\mu \mathrm{g}$ (g dry $\mathrm{wt})^{-1}$ ). Tissue concentrations were not statistically different among stations, but were elevated in individual samples at AT in the San Joaquin River and SM in
Suisun Bay. Mississippi silversides contained similar amounts of total microcystins in liver and muscle tissue as striped bass (Table 2). As might be expected, total microcystins concentration in the whole body tissue of Mississippi silversides was more than an order of magnitude lower than for liver and muscle tissue alone. Absolute total microcystins concentrations and differences in concentration among samples were probably lower than the actual values due to the need to composite from 2 to 10 fish tissue samples for toxin analysis from these very small fish; this was particularly true for liver samples.

\section{Histopathology}

Histopathological analysis revealed that Mississippi silversides and juvenile striped bass were likely 
exposed to toxic substances including cancer causing substances throughout the estuary. Several types of histological changes were observed in juvenile striped bass liver tissue. Mild to moderate glycogen depletion occurred in liver tissue for all stations (Fig. 9). Mild, but elevated lesion scores for cytoplasmic inclusion, single cell necrosis and lipidosis also suggested the striped bass in the Sacramento River and San Joaquin Rivers were exposed to toxic contaminants and cancer causing substances. Hepatic preneoplastic foci and the presence of tumors in liver tissue further supported the exposure of striped bass at station AT to cancer causing substances in the San Joaquin River. Importantly, elevated lesion scores for cancer causing substances and the presence of tumors in striped bass liver coincided with elevated concentrations of total microcystins at AT. Liver lesion scores for the San Joaquin River differed from those in Suisun Bay where the maximum lesion scores resulted from a different suite of biomarkers, such as eosinophilic protein droplets, macrophage aggregates, and focal parenchymal leukocytes.

The liver tissue of Mississippi silversides also demonstrated histological changes characteristic of exposure to toxic substances throughout the estuary. Like striped bass, glycogen depletion was mild to moderate at most stations (Fig. 10). Liver lesion scores characteristic of exposure to toxic substances, single cell necrosis, and cytoplasmic inclusions, occurred in liver tissue for fish in San Joaquin River and Suisun Bay, while those for hepatic lipidosis were moderately elevated in liver tissue for Suisun Bay and Old River. Maximum lesion scores in liver tissue for glycogen depletion, eosinophilic protein droplets, and cytoplasmic inclusions occurred in Suisun Bay and San Joaquin River, Sacramento River, and the San Joaquin River, respectively. All of the remaining lesion scores were highest for Mississippi silversides in Suisun Bay at station CI.

\section{Discussion}

Phytoplankton

Microcystis forms dense surface blooms that may exert a pronounced effect on the surrounding plankton through its effect on the quantity and quality of the light field in the water column in the presence of 
Fig. 9 Average liver lesion scores for each biomarker quantified in juvenile striped bass collected at stations throughout the estuary. No fish were present at stations FT and OR

Fig. 10 Average liver lesion scores for each biomarker quantified in Mississippi silversides collected at stations throughout the estuary
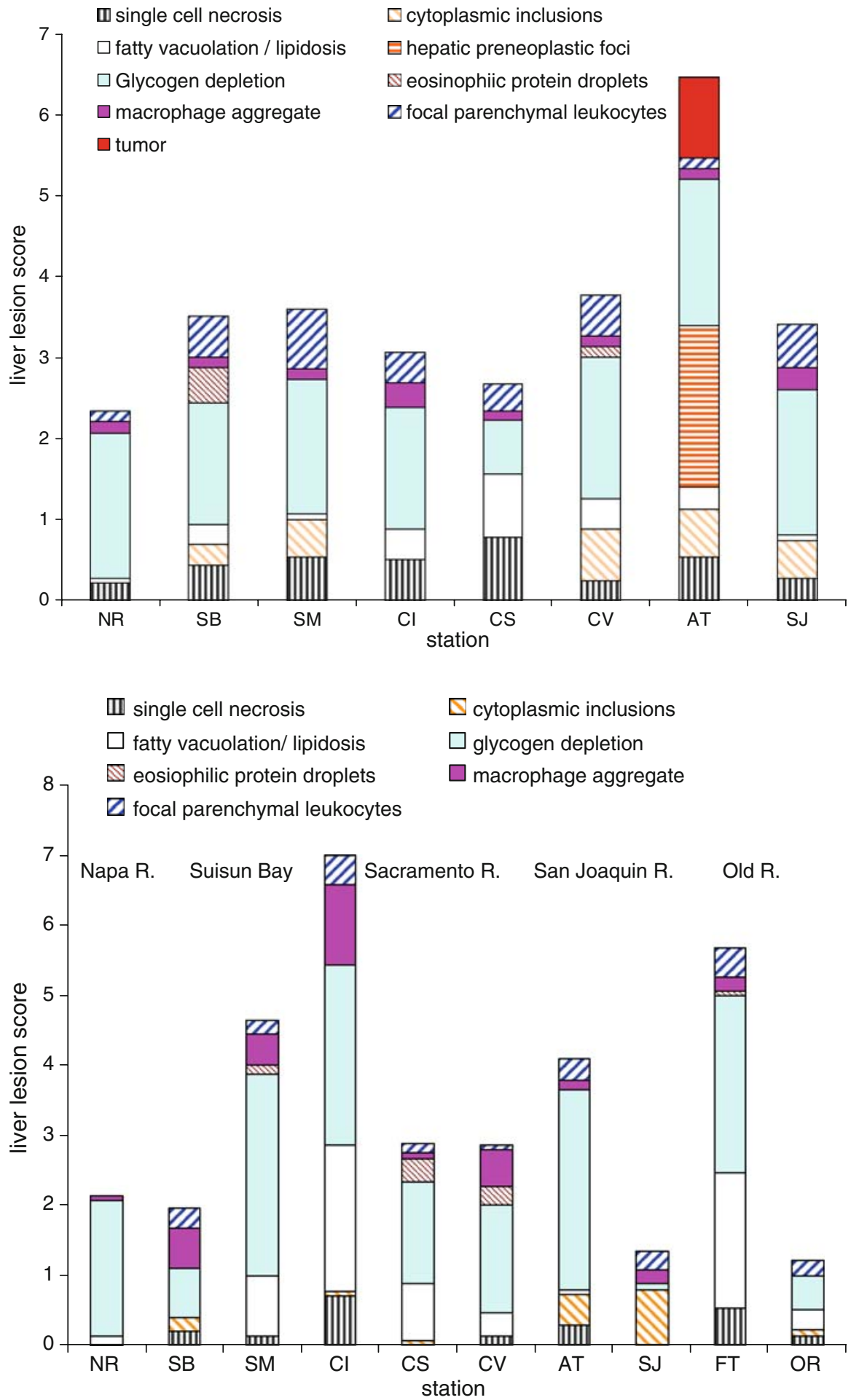

carbonate concentrating mechanisms (Giordano et al., 2005) and nutrient uptake (Marinho \& Azevedo, 2007). Microcystis contain gas vesicles that allow them to float on the surface of the water column where they can decrease light availability and primary productivity for plankton below the surface. 
This may partly explain the decreased density of diatom, green algae, and other cyanobacteria at $1 \mathrm{~m}$ depth compared with cryptophytes with flagella that enable them to adjust their light position in the water column. Microcystis can alter the $\mathrm{pH}$, and hence inhibit $\mathrm{CO}_{2}$ uptake, giving preference to cyanobacteria with their enhanced carbonate concentrating capabilities (Giordano et al., 2005). However, the $\mathrm{pH}$ among the stations did not differ, suggesting that differences in carbonate concentrating mechanisms were not important in SFE. Microcystis co-occured with Aphanizomenon spp. This filamentous cyanobacterium has similar enhanced carbonate and light capturing capabilities through carboxysome and phycobilisomes as Microcystis, but because it has heterocysts that produce nitrogen needed for growth, it does not compete with Microcystis for nitrogen (Paerl et al., 2001). Microcystis is extremely flexible in its ability to use organic nitrogen and phosphorus and alternative forms of nutrients may provide a selective advantage for this species even though nutrients are rarely limiting in SFE (Jassby, 2005). Recent increases in ammonium concentration in the western delta may give a competitive advantage to Microcystis which rapidly assimilates ammonium over nitrate (Blomqvist et al., 1994; Jassby, 2005). However, recent reductions in river flow may have had a greater influence on abundance (Kuwata \& Miyazaki, 2000; Lehman et al., 2008).

Microcystis may have affected plankton community composition through allelopathy by the production of microcystins or other bioactive peptides. Microcystins were associated with a decrease in diatom density and increase in the growth rate and number of cyanobacteria species in laboratory cultures (Sedmak \& Kosi, 1998; Suikkanen et al., 2005). Microcystins may not have affected some phytoplankton, such as the chain diatom Aulacoseira granulata or the green alga Monoraphidinium contortum in SFE, which were common in the surface layer. Laboratory studies suggest these species grow well in the presence of Microcystis (Sedmak \& Kosi, 1998; Jia et al., 2008). Microcystis can inhibit photosynthesis and the growth rate of the cyanobacteria Nostoc spp., Anabaena spp., and Synechocystis spp. (Vassilakaki \& Pflugmacher, 2008; Singh et al., 2001) and may contribute to their absence or low density in SFE. The impact of Microcystis on algal growth is often species specific. Microcystis inhibited chlorophyll a synthesis in Scenedesmus obliquus, but increased the growth of Scenedesmus quadricauda in laboratory cultures (Sedmak \& Kosi, 1998; Jia et al., 2008). Dissolved microcystins can also affect cell aggregation, increase cell volume, and production of photosynthetic pigments in Scenedesmus quadricauda (Sedmak \& Eleršek, 2006). Scenedesmus spp. was not found in the surface or $1 \mathrm{~m}$ samples where Microcystis was abundant for this study, but has been a common species in the delta over time (www. iep.water.ca.gov). The increased abundance of the cryptophytes Rhodomonas spp. and Crytomonas spp. in SFE may also be due to species specific responses to Microcystis. Although elevated Microcystis abundance was associated with decreased abundance of the cryptophyte Cryptomonas arosa (Sedmak \& Kosi, 1998), cryptophyte growth varied among species when exposed to filtrates from freshwater and brackish water cyanobacteria including Nodularia, Aphanizomenon, and Anabaena (Suikkanen et al., 2005). The mechanisms associated with the allelopathy of Microcystis are poorly understood, but the growth and photosynthesis of Peridinium gatunense were decreased by inhibition of carbonic anhydrase activity (Sukenik et al., 2002).

The loss of diatom and green algal carbon and increase in cryptophyte carbon associated with elevated Microcystis abundance was sufficient to affect the quantity and quality of the phytoplankton carbon available to the food web in SFE. Diatom and green algae have some of the largest cells by volume in the phytoplankton community within SFE, therefore their loss can remove a large portion of the total carbon available to the food web (Lehman, 1996). Because cryptophytes have a relatively low average biovolume, the increase in their carbon was insufficient to compensate for the loss of diatom and green algal carbon. This was true even though most of the cryptophyte carbon was composed of two relatively large volume species, Rhodomonas spp. and Cryptomonas spp. A decrease in the diatom and green algal biovolume was also associated with an increase in cyanobacteria and cryptophyte biovolume between 1975 and 1993 in SFE, but it was attributed to long term changes in environmental conditions, particularly flow (Lehman, 2000a). Nutrient concentrations are often thought to be the primary driver of plankton blooms, particularly cyanobacteria blooms (Paerl et al., 2001). Recent research suggested haptophytes, 
chlorophytes, and dinoflagellates increase with ammonium-N concentration in the Neuse River estuary (Rothenberger et al., 2009). However, nutrient concentration, including ammonium-N concentration and the NP molar ratio, did not account for the majority of the variation in Microcystis abundance in the surface layer or the distribution phytoplankton carbon among classes at $1 \mathrm{~m}$ depth for this study.

\section{Zooplankton}

Zooplankton carbon was positively correlated with Microcystis abundance. Most of the zooplankton carbon occurred in the western and central delta, and was composed of calanoid copepods. Copepods can actively reject toxic strains of Microcystis, and, therefore, are less likely to be affected by toxic blooms at low to moderate levels (DeMott \& Moxter, 1991). In addition, some zooplankton can effectively use decomposed Microcystis as a food source (Hanazato \& Yasuno, 1987). Copepod biomass was also not affected by Microcystis biomass in Steele Lake, Canada (Ghadouani et al., 2003). It is likely that the gradual seaward decrease in copepod carbon, dominated by the freshwater copepod $P$. forbesii, was due to other factors such as salinity or clam grazing in SFE (Kimmerer, 2004).

However, it is also possible that the presence of Microcystis and its toxins in the western and central delta affected the ability of calanoid copepods to reach maximum population levels. $P$. forbesii decreased in the western and central delta after 1999 and coincided with the appearance of Microcystis blooms (Lehman et al., 2005; Sommer et al., 2007). Although initial laboratory feeding studies indicated one of the common copepods in SFE, Eurytemora affinis, did not consume Microcystis, zooplankton tissue in SFE contained microcystins (Lehman et al., 2005, 2008). In Chesapeake Bay, zooplankton can consume some Microcystis even though they do not actively feed on this cyanobacterium (Sellner et al., 1993). Recent laboratory feeding studies confirmed that the survival of both P. forbesii and E. affinis was reduced when Microcystis exceeded $10 \%$ of the diet, and that P. forbesii was three times more sensitive than E. affinis (Ger et al., 2009). Dissolved microcystins also affect zooplankton growth and survival and can increase in the presence of zooplankton (Jang et al., 2003).
Dissolved microcystins occurred occasionally and may have contributed to the variability in zooplankton composition and biomass.

Elevated Microcystis biomass was associated with a low cladocera to calanoid copepod ratio. Microcystis blooms are often associated with low cladocera biomass because large cladocera like Daphnia sp. are more sensitive to Microcystis than small cladocera (Chen et al., 2007). Microcystis is a poor quality food and both toxic and non-toxic Microcystis adversely affect cladocera survival, growth rate, reproduction rate, clutch size, feeding rate, and nutrition (Reinikainen et al., 1999; Rohrlack et al., 2001, 2005; Wilson et al., 2006; Abrantes et al., 2006; Federico et al., 2007). Microcystis blooms can also affect the growth rate of cladocera by physically inhibiting feeding (Lurling, 2003). The Microcystis strain may also be important in SFE where DNA analysis suggested the western delta had different and more toxic Microcystis strains than the central delta (Moisander et al., 2009; D. Baxa, personal communication).

\section{Fish}

Toxic Microcystis may adversely affect fish health in the estuary when hepatotoxic microcystins cause liver damage and tumors (Malbrouck \& Kestemont, 2006; Ibelings \& Havens, 2008). Five of the lesion types evaluated in this study, single cell necrosis, cytoplasmic inclusions, hepatic lipidosis, hepatic preneoplastic foci, and hepatocellular adenoma (tumor) are likely pathologic responses to toxic exposure in fish (Teh et al., 1997; Malbrouck \& Kestemont, 2006). The combined presence of these lesions in juvenile striped bass liver tissue suggests fish in the Sacramento and San Joaquin River were recently exposed to toxins. Low concentrations in fish tissue may indicate the rapid depuration of microcystins or toxin dilution through the food web (Ibelings \& Havens, 2008). The presence of hepatic preneoplastic foci and hepatocellular adenoma in these young fish suggests the toxin was carcinogenic and affecting the fish at a very early life stage, which is atypical. We hypothesize that microcystins within the Microcystis colonies either contributed to or were the cause of these histopathological changes in striped bass liver tissue in the San Joaquin River, especially at station AT where the combined presence of the five lesion types 
coincided with high total microcystins concentration. Ongoing research suggests Microcystis populations can be more toxic at AT than other stations in the estuary (D. Baxa, personal communication). Single cell necrosis and cytoplasmic inclusions in the liver tissue of Mississippi silversides further supported the contaminant exposure of fish in the lower San Joaquin River to Microcystis toxins. Dissolved microcystins may have contributed to the observed lesion scores, but anatoxin-a concentrations were probably too low.

\section{Food web}

Through its impact on multiple trophic levels, Microcystis may influence fishery production including the decline in pelagic organisms measured since 2000 in SFE (Sommer et al., 2007). The effects of Microcystis on food web organisms suggested by this study include direct impacts through nutrients, light, allelopathy, or toxicity on the growth and survival of phytoplankton, zooplankton, and fish or indirect impacts through the food web. The potential impact of Microcystis on phytoplankton group carbon maybe important for fishery production in SFE where the health and survival of key zooplankton food species like $P$. forbesii rely on the abundance of wide diameter diatom and green algae cells that provide good quality food in the optimum size range for filtering feeding (Müller-Navarra et al., 2000; Lehman, 2000b). This was supported by the strong positive correlation between total zooplankton and Neomysis shrimp carbon with diatom carbon between 1975 and 1993 in the estuary (Lehman, 2004), particularly after the depletion of diatoms following the invasion of the overbite clam in 1987 (Kimmerer, 2004). Although cladocera carbon was only a small percentage of the total zooplankton carbon compared with copepods, the decrease in the cladocera to calanoid copepod ratio may directly affect food availability for threadfin shad (T. Sommer, personal communication), an important forage species for picivores in SFE (Nobriga \& Feyrer, 2007). Importantly, the impact of Microcystis on the aquatic community may be greater than suggested by impacts on copepods and cladocera. Microcystins are commonly present throughout the food web, and in SFE were measured in clams, worms, and jellyfish that also serve as food resources for fish (Ibelings \&
Havens, 2008; Lehman et al., 2005, 2008). Identifying the full impact of Microcystis on the SFE food web requires further information on high frequency spatial and temporal variability of the aquatic food web and body burdens across a larger suite of species and trophic levels.

Acknowledgments This project was funded by a special study grant from the San Francisco Bay Delta Interagency Ecological Program. Special thanks are due to many including E. Santos, F. Feyrer, and M. Dempsey for assistance with sampling, M. Bettencourt for phytoplankton counts and M. Satchwell (SUNY-ESF) for PPIA toxin analysis.

Open Access This article is distributed under the terms of the Creative Commons Attribution Noncommercial License which permits any noncommercial use, distribution, and reproduction in any medium, provided the original author(s) and source are credited.

\section{References}

Abrantes, N., S. C. Antunes, M. J. Pereira \& F. Goncalves, 2006. Seasonal succession of cladocerans and phytoplankton and their interactions in a shallow eutrophic lake (Lake Vela, Portugal). Acta Oecologica 29: 54-64.

Agrawai, M. K., D. Bagchi \& S. N. Bagchi, 2001. Acute inhibition of protease and suppression of growth in zooplankter, Moina macrocopa, by Microcystis blooms collected in Central India. Hydrobiologia 464: 37-44.

American Public Health Association, American Water Works Association \& Water Environment Association, 1998. Standard Methods for the Examination of Water and Wastewater, 20th edn. American Public Health Association, Washington, DC, USA.

Best, J. H., F. B. Eddy \& G. A. Codd, 2001. Effects of purified microcystin-LR and cell extracts of Microcystis strains PCC 7813 and CYA 43 on cardiac function in brown trout (Salmo trutta) alevins. Fish Physiology and Biochemistry 24: 171-178.

Best, J. H., S. Pflugmacher, C. Wiegand, F. B. Eddy, J. S. Metcalf \& G. A. Codd, 2002. Effects of enteric bacterial and cyanobacterial lipopolysaccharides, and of microcystin-LR, on glutathione S-transferase activities in zebra fish (Danio rerio). Aquatic Toxicology 60: 223-231.

Best, J. H., F. B. Eddy \& G. A. Codd, 2003. Effects of Microcystis cells, cell extracts and lipopolysaccharide on drinking and liver function in rainbow trout Oncorhynchus mykiss Walbaum. Aquatic Toxicology 64: 419-426.

Bláha, L., R. Kopp, K. Šimková \& J. Mares, 2004. Oxidative stress biomarkers are modulated in silver carp (Hypophalmichthys molitrix Val.) exposed to microcystin-producing cyanobacterial water bloom. Acta Veterinaria Brno 73: 477-482.

Blomqvist, P., A. Petterson \& P. Hyenstrand, 1994. Ammonium-nitrogen: a key regulatory factor causing dominance 
of non-nitrogen-fixing cyanobacteria in aquatic systems. Archiv für Hydrobiologie 132: 141-164.

Chen, F., P. Xie \& B. Qin, 2007. Different competitive outcomes among four species of cladocerans under different alga combinations of colonial Microcystis spp. and green alga Scenedesmus obliquus. Hydrobiologia 581: 209-215.

Chorus, I., 2005. Current approaches to cyanotoxin risk assessment, risk management and regulations in different countries. Federal Environmental Agency, Berlin.

Clarke, K. R., 1993. Non-parametric multivariate analyses of changes in community structure. Australian Journal of Ecology 18: 117-143.

Clarke, K. R. \& R. N. Gorley, 2006. PRIMER v6: User Manual/Tutorial. PRIMER-E, Plymouth.

De Magalthães, V. F., R. M. Soares \& S. M. F. O. Azevedo, 2001. Microcystin contamination from fish in the Jacarepaquá Lagoon (Rio de Janeiro Brazil): ecological implication and human risk. Toxicon 39: 1077-1085.

DeMott, W. R. \& F. Moxter, 1991. Foraging cyanobacteria by copepods: responses to chemical defense and resource abundance. Ecology 72: 1820-1834.

Federico, A., S. S. S. Sarma \& S. Nandini, 2007. Effect of mixed diets (cyanobacteria and green algae) on the population growth of the cladocerans Ceriodaphnia dubia and Moina macrocopa. Aquatic Ecology 41: 579-585.

Ferrão-Filho, A. S., S. M. F. O. Azevedo \& W. R. DeMott, 2002. Effects of toxic and non-toxic cyanobacteria on the life history of tropical and temperate cladocerans. Freshwater Biology 45: 1-19.

Fischer, W. J. \& D. R. Dietrich, 2000. Pathological and biochemical characterization of microcystin-induced hepatopancreas and kidney damage in carp (Cyprinus carpio). Toxicology and Applied Pharmacology 164: 73-81.

Fristachi, A., J. L. Sinclair, J. A. Hambrook-Berkman, G. Boyer, J. Burkholder, J. Burns, W. Carmichael, A. du Four, W. Frazier, S. L. Morton, E. O'Brien \& S. Walker, 2008. Occurrence of Cyanobacterial Harmful Algal Blooms working group report. In Hudnell, H. K. (ed.), Proceedings of the Interagency International Symposium on Cyanobacterial Harmful Algal Blooms, Vol. 619. Advances Experimental Medical Biology. Springer, New York: 37-97.

Ger, K. A., S. J. Teh \& C. R. Goldman, 2009. Microcystin-LR toxicity on dominant copepods Eurytemora affinis and Pseudodiaptomus forbesi of the upper San Francisco Estuary. Science of the Total Environment 407: 48524857.

Ghadouani, A., B. Pinel-Alloul \& E. E. Prepas, 2003. Effects of experimentally induced cyanobacterial blooms on crustacean zooplankton communities. Freshwater Biology 48: 363-381.

Ghadouani, A., B. B. Pinel-Alloul, K. Plath, G. A. Codd \& W. Lampert, 2004. Effects of Microcystis and purified microcystin-LR on the feeding behavior of Daphnia pulicaria. Limnology and Oceanography 49: 666-679.

Ghadouani, A., B. B. Pinel-Alloul \& E. E. Prepas, 2006. Could increased cyanobacterial biomass following forest harvesting cause a reduction in zooplankton body size structure? Canadian Journal of Fisheries and Aquatic Sciences 63: 2308-2317.
Giordano, M., J. Berdall \& J. A. Raven, 2005. $\mathrm{CO}_{2}$ concentrating mechanisms in Algae: mechanisms, environmental modulation and evolution. Annual Review Plant Biology 56: 99-131.

Graneli, E., P. Salomon \& G. Fistarol, 2008. The role of allelopathy for harmful algal bloom formation. In Evangelista, V., L. Barsanti, A. Frassanito, V. Passarelli \& P. Gualtieri (eds), Algal Toxins: Nature, Occurrence, Effect and Detection. NATO Science for Peace and Security Series A: Chemistry and Biology. Springer, Netherlands: 159-178.

Gustafsson, S. \& L. Hansson, 2004. Development of tolerance against toxic cyanobacteria in Daphnia. Aquatic Ecology 38: $37-44$.

Hanazato, T. \& M. Yasuno, 1987. Evaluation of Microcystis as food for zooplankton in a eutrophic lake. Hydrobiologia 144: 251-259.

Ibelings, B. W. \& K. E. Havens, 2008. Cyanobacterial toxins: a qualitative meta-analysis of concentrations, dosage and effects in freshwater estuarine and marine biota. In Hudnell H. K. (ed.), Cyanobacterial Harmful Algal Blooms: State of the Science and Research Needs, Vol. 619. Advances in Experimental Medicine and Biology. Springer, New York: 675-732.

International Agency for Research on Cancer, 2006. Carcinogenicity of nitrate, nitrite, and cyanobacterial peptide toxins. The Lancet Oncology 7: 628-629.

Jang, M., K. Ha, G. Joo \& N. Takamura, 2003. Toxin production of cyanobacteria is increased by exposure to zooplankton. Freshwater Biology 48: 1540-1550.

Jassby, A. D., 2005. Phytoplankton regulation in a eutrophic tidal river (San Joaquin River, California). San Francisco Estuary and Watershed Science 3(1), Article 3.

Jia, X., D. Shi, R. Kang, H. Li, Y. Liu, Z. An, S. Wang, D. Song \& G. Du, 2008. Allelopathic inhibition by Scenedesmus obliquus of photosynthesis and growth of Microcystis aeruginosa. In Allen, J. F., E. Gantt, J. H. Golbeck \& B. Osmond (eds), Photosynthesis. Energy from the Sun: $14^{\text {th }}$ International Congress on Photosynthesis. Springer, Heidelberg: 1339-1342.

Kimmerer, W. J., 2004. Open water processes of San Francisco Estuary: from physical forcing to biological responses. San Francisco Estuary and Watershed Science 2(1), Article 1.

Komárek, J. \& K. Anagnostidis, 2001. Cyanoprokaryota 1, Teil: Chroococcales. In Ettl, H., G. Gartner, H. Heynig \& D. Mollenhauer (eds), Susswasserflora von Mitteleuropa 19(1). Jena, Verlag von G. Fischer, Germany.

Kuwata, A. \& T. Miyazaki, 2000. Effects of ammonium supply rates on competition between Microcystis novacekii (Cyanobacteria) and Scenedesmus quadricauda (Chlorophyta): simulation study. Ecological Modeling 135: 81-87.

Legrand, C., K. Rengefors, G. O. Fistarol \& E. Graneli, 2003. Allelopathy in phytoplankton: biochemical, ecological and evolutionary aspects. Phycologia 42: 406-419.

Lehman, P. W., 1996. Changes in chlorophyll $a$ concentration and phytoplankton community composition with wateryear type in the upper San Francisco Bay Estuary. In Hollibaugh, J. T. (ed.), San Francisco Bay: The Ecosystem. Pacific Division of the American Association for the Advancement of Science, San Francisco, CA: 351-374. 
Lehman, P. W., 2000a. The influence of climate on phytoplankton community carbon in San Francisco Bay Estuary. Limnology and Oceanography 45: 580-590.

Lehman, P. W., 2000b. Phytoplankton biomass, cell diameter and species composition in the low salinity zone of northern San Francisco Bay Estuary. Estuaries 23: 216-230.

Lehman, P. W., 2004. The influence of climate on mechanistic pathways that impact lower food web production in northern San Francisco Bay estuary. Estuaries 27: 311-324.

Lehman, P. W., G. Boyer, C. Hall, S. Waller \& K. Gehrts, 2005. Distribution and toxicity of a new colonial Microcystis aeruginosa bloom in the San Francisco Bay Estuary, California. Hydrobiologia 541: 87-90.

Lehman, P. W., G. Boyer, M. Satchwell \& S. Waller, 2008. The influence of environmental conditions on the seasonal variation of Microcystis abundance and microcystins concentration in San Francisco Estuary. Hydrobiologia 600: 187-204.

Lurling, M., 2003. Daphnia growth on microcystin-producing and microcystin-free Microcystis aeruginosa in different mixtures with the green alga Scenedesmus obliquus. Limnology and Oceanography 48: 2214-2220.

Malbrouck, C. \& P. Kestemont, 2006. Effects of microcystins on fish. Environmental Toxicology and Chemistry 25: 72-86.

Marinho, M. M. \& S. M. F. O. Azevedo, 2007. Influence of N/P ratio on competitive abilities for nitrogen and phosphorus by Microcystis aeruginosa and Aulacoseira distans. Aquatic Ecology 41: 525-533.

Menden-Deuer, S. \& E. J. Lessard, 2000. Carbon to volume relationships for dinoflagellates, diatoms and other protest plankton. Limnology and Oceanography 45: 569-579.

Moisander, P. H., P. W. Lehman, M. Ochiai \& S. Corum, 2009. Diversity of the toxic cyanobacterium Microcystis aeruginosa in the Klamath River and San Francisco Bay delta, California. Aquatic Microbial Ecology 57: 19-31.

Müller-Navarra, D. C., M. T. Brett, A. M. Liston \& C. R. Goldman, 2000. A highly unsaturated fatty acid predicts carbon transfer between primary producers and consumers. Nature 403: 74-77.

Nobriga, M. L., \& F. Feyrer, 2007. Shallow-water piscivoreprey dynamics in California's Sacramento-San Joaquin Delta. San Francisco Estuary and Watershed Science 5 [available on internet at http://repositories.cdlib.org/jmie/ sfews/vol5/iss2/art4].

Nobriga, M. L., F. Feyrer, R. D. Baxter \& M. Chotkowski, 2005. Fish community ecology in an altered river delta: spatial patterns in species composition, life history strategies and biomass. Estuaries 28: 776-785.

Paerl, H. W., 1988. Nuisance phytoplankton blooms in coastal, estuarine and inland waters. Limnology and Oceanography 33: 823-847.

Paerl, H. W., R. S. Fulton, P. H. Moisander \& J. Dyble, 2001. Harmful freshwater algal blooms, with an emphasis on cyanobacteria. The ScientificWorld 1: 76-113.

Palíková, M., R. Krejčí, K. Hilscherová, P. Babica, S. Navrátil, R. Kopp \& L. Bláha, 2007. Effect of different cyanobacterial biomasses and their fractions with variable microcystin content on embryonal development of carp (Cyprinus carpio L.). Aquatic Toxicology 81: 312-318.

Prieto, A. I., S. Pichardo, A. Josa, I. Moreno \& A. M. Cameán, 2007. Time-dependent oxidative stress responses after acute exposure to toxic cyanobacterial cells containing microcystins in tilapia fish (Oreochromis niloticus) under laboratory conditions. Aquatic Toxicology 84: 337-345.

Reinikainen, M., J. Hietala \& M. Walls, 1999. Reproductive allocation in Daphnia exposed to toxic cyanobacteria. Journal of Plankton Research 21: 1553-1564.

Robson, B. J. \& D. P. Hamilton, 2003. Summer flow event induces a cyanobacterial bloom in a seasonal Western Australia estuary. Marine Freshwater Research 54: 139-151.

Rocha, C., H. Galvão \& A. Barbosa, 2002. Role of transient silicon limitation in the development of cyanobacteria blooms in the Guadiana estuary, south-western Iberia. Marine Ecology Progress Series 228: 35-45.

Rohrlack, T., E. Dittmann, T. Börner \& K. Christoffersen, 2001. Effects of cell-bound microcystin on survival and feeding of Daphnia spp. Applied Environmental Microbiology 67: 3523-3529.

Rohrlack, T., K. Christoffersen, E. Dittmann, I. Nogueira, V. Vasconcelos \& T. Borner, 2005. Ingestion of microcystins by Daphnia: Intestinal uptake and toxic effects. Limnology and Oceanography 50: 440-448.

Rothenberger, M. B., J. M. Burkholder \& T. R. Wentworth, 2009. Use of long-term data and multivariate ordination techniques to identify environmental factors governing estuarine phytoplankton species dynamics. Limnology and Oceanography 54: 2107-2127.

SAS Institute, Inc., 2004. SAS/STAT User's Guide, Version 8. SAS Institute Inc., SAS Campus Drive, Cary, NC, USA.

Sedmak, B. \& T. Eleršek, 2006. Microcystins induce morphological and physiological changes in selected representative phytoplanktons. Microbial Ecology 51: 508-515.

Sedmak, B. \& G. Kosi, 1998. The role of microcystins in heavy cyanobacterial bloom formation. Journal of Plankton Research 20: 691-708.

Sellner, K. G., R. V. Lacouture \& K. G. Parlish, 1988. Effect of increasing salinity on a cyanobacteria bloom in the Potomac River Estuary. Journal of Plankton Research 10: 49-61.

Sellner, K. G., D. C. Brownleee, M. H. Bundy, S. G. Brownlee \& K. R. Braun, 1993. Zooplankton grazing in a Potomac River cyanobacteria bloom. Estuaries 16: 859-872.

Singh, D. P., M. B. Fyagi, A. Kumar \& J. K. Thakur, 2001. Antialgal activity of a hepatotoxin-producing cyanobacterium, Microcystis. World Journal of Microbiology and Biotechnology 17: 15-22.

Smith, J. L. \& G. L. Boyer, 2009. Standardization of microcystin extraction from fish tissues: a novel internal standard as a surrogate for polar and non-polar variants. Toxicon 53: 238-245.

Smith, J. L., G. L. Boyer \& P. V. Zimba, 2008. A review of cyanobacterial odorous and bioactive metabolites: impacts and management alternatives in aquaculture. Aquaculture 280: 5-20.

Sommer, T. R., C. Armor, R. Baxter, R. Breuer, L. Brown, M. Chotkowski, S. Culberson, F. Feyrer, M. Gingras, B. Herbold, W. Kimmerer, A. Mueller-Solger, M. Nobriga \& K. Souza, 2007. The collapse of pelagic fishes in the upper San Francisco Estuary. Fisheries 32: 270-277.

Suikkanen, S., G. O. Fistarol \& E. Granéli, 2005. Effects of cyanobacterial allelochemicals on a natural plankton community. Marine Ecology Progress Series 287: 1-9. 
Sukenik, A., R. Eshkol, A. Livne \& O. Hadas, 2002. Inhibition of growth and photosynthesis of the dinoflagellates Peridinium gatunense by Microcystis sp. (cyanobacteria): a novel allelopathic mechanism. Limnology and Oceanography 47: 1656-1663.

Teh, S. J., S. M. Adams \& D. E. Hinton, 1997. Histopathologic biomarkers in feral fish populations exposed to different types of contaminant stress. Aquatic Toxicology 37: 51-70.

Teh, S. J., X. Deng, D.-F. Deng, F. C. Teh, S. S. O. Hung, WM. T. Fan, J. Liu \& R. Higashi, 2004. Chronic effects of dietary selenium on juvenile Sacramento splittail (Pogonichthys macrolepidotus). Environmental Science and Technology 38: 6085-6093.

United States Environmental Protection Agency, 1983. Methods for Chemical Analysis of Water and Wastes. Technical Report EPA-600/4-79-020, Washington, DC.

United States Geological Survey, 1985. Methods for Determination of Inorganic Substances in Water and Fluvial Sediments. Open File Report: 85-495.

Utermöhl, H., 1958. Zur Vervollkommnung der quantitativen Phytoplankton-methodik. Mitteilumgen Internationale Verejunigung fur Theoretische und Angewandtet Limnologie 9: 1-38.
Van der Oost, R., J. Beyer \& N. P. E. Vermeulen, 2003. Fish bioaccumulation and biomarkers in environmental risk assessment: a review. Environmental Toxicology and Pharmacology 13: 57-149.

Vassilakaki, M. \& S. Pflugmacher, 2008. Oxidative stress response of Synechocystis sp. (PCC 6803) due to exposure to microcystin-LR and cell-free cyanobacterial crude extract containing microcystin-LR. Journal of Applied Phycology 20: 219-225.

Wehr, J. D. \& R. G. Sheath, 2003. Freshwater Algae of North America, Ecology and Classification. Elsevier Science, San Diego, USA.

Wilson, A. E. \& M. E. Hay, 2007. A direct test of cyanobacterial chemical defense: variable effects of microcystintreated food on two Daphnia pulicaria clones. Limnology and Oceanography 52: 1467-1479.

Wilson, A. E., O. Sarnelle \& A. R. Tillmanns, 2006. Effects of cyanobacterial toxicity and morphology on the population growth of freshwater zooplankton: meta-analysis of laboratory experiments. Limnology and Oceanography 51: 1915-1924.

Zegura, B., B. Sedmak \& M. Filipi, 2003. Microcystin-LR induces oxidative DNA damage in human hepatoma cell line HepG2. Toxicon 41: 41-48. 